\title{
Preparation and Characterization of Near Nano Copper Powder by Electrolytic Route
}

\author{
Akansha Sengar, Prathvi Raj Soni \\ Department of Metallurgical \& Materials Engineering, Malaviya National Institute of Technology, Jaipur, India \\ Email: psmt@rediffmail.com
}

Received 20 September 2014; revised 15 October 2014; accepted 21 October 2014

Copyright (C) 2014 by authors and Scientific Research Publishing Inc.

This work is licensed under the Creative Commons Attribution International License (CC BY). http://creativecommons.org/licenses/by/4.0/

c) (i) Open Access

\begin{abstract}
For the preparation of copper nanoparticles several methods, i.e., thermal reduction, mechanical attrition, chemical reduction metal vapour synthesis, radiation methods, laser ablation and micro emulsion techniques were developed in the past. Electrolytic deposition is one of the most suitable, simplest and low cost methods which are used for wide range of materials. In the present investigations, efforts were put to produce copper nano powder using electrolytic technique. It could be possible to obtain near nano copper powder of $258 \mathrm{~nm}$ size using high cathode current density of $1100 \mathrm{~A} / \mathrm{m}^{2}$ in sulphate bath. The specific surface area and shape of the particles were found to be $23.2 \mathrm{~m}^{2} / \mathrm{g}$ and irregular, respectively.
\end{abstract}

\section{Keywords}

Near Nano Copper Powder, Sulphate Bath, Size and Size Distribution, Morphology

\section{Introduction}

The field of nanoscience and nanotechnology has recently become one of the most important areas of knowledge encompassing various scientific disciplines, including physics, chemistry, biology and engineering. Interest in this discipline is mainly due to two reasons. Firstly, nano scale materials have many prospects in various technological applications because most of the time they show novel functionalities. Secondly, there is a tremendous scope of creating new knowledge in explaining the size dependencies of the evolution of various physical properties, and in explaining new and previously unnoticed features. Nanostructured materials can be utilized in fabricating novel active devices with improved functionalities. For example, one dimensional nanomaterial (tubes, wires, rods, etc.) is an important class of nanostructured materials with potential applications in electronics, composite fabrications or sensor developments [1].

Mainly nanotechnology is the ability to form nano-sized particles, for example nano powders, which are solid 
particles that measure on the nano scale, usually comprised of 3 to 5 molecules together. Nano powders can be used in most of the aforementioned applications; so, it has been an interesting field of great interest [2]. The considerable interest has been focused on metal nanoparticles due to their potential applications and special properties in diverse fields.

Among various non-metal and metal particles, copper nanoparticles have attracted considerable attention because of their catalytic, optical, and electrical conducting properties. For the preparation of copper nanoparticles several methods were developed, i.e., thermal reduction, mechanical attrition, chemical reduction, metal vapour synthesis, radiation methods, laser ablation and micro emulsion techniques. In nanoparticle preparation, it is very important to control the particle size, particle shape and morphology. Most of the preparation procedures have some factors that restrict the use and development of the copper nanoparticles. For example, copper nanoparticles synthesized by mechanical chemical method have low purity and wide particle size distribution. Gas evaporation method presents the costly raw materials and complicated equipment [3]. Nanoparticles synthesized in lithographic and by vacuum deposition provide uniform shape, size and size distribution, but these techniques are expensive.

Electrolytic deposition is one of the most suitable, simplest and low cost methods which are used for wide range of materials and characteristics [4]. Therefore, in the present investigations, it was planned to produce nano copper powder by using electrolytic deposition from copper sulphate bath under suitable bath conditions [5] and additives like boric acid and glycerine [6].

\section{Experimental}

Copper sulphate bath was prepared by dissolving $\mathrm{CuSo}_{4} \cdot 5 \mathrm{H}_{2} \mathrm{O}$ ( $99 \%$ purity) in distilled water EC grade copper was used as anode and stainless steel as cathode. The experimental conditions under which the copper powder was prepared have been summarized in Table 1 .

The deposited copper powder was removed by brushing after every 15 minutes and washed thoroughly with distilled water. Subsequently the powder was dried in the air atmosphere. This powder sample was then deagglomerated in a mortar pestle to obtain the final product. Copper powder samples were also prepared after adding $1 \mathrm{wt} \%$ of boric acid or glycerine to the electrolyte bath.

The resultant powder was tested for its purity using EDS analysis. Particle size, size distribution and specific surface area of the powder produced was studied by laser technique using Malvern Mastersizer 2000, while the morphology was studied using ZEISS Supra-50 FESEM.

\section{Results and Discussion}

The electrolyte copper sulphate when dissolved in water dissociates to give $\mathrm{Cu}^{2+}$ and $\mathrm{SO}_{4}^{2-}$ ions.

$$
\mathrm{CuSO}_{4}(\mathrm{aq}) \rightarrow \mathrm{Cu}^{2+}(\mathrm{aq})+\mathrm{SO}_{4}^{2-}(\mathrm{aq})
$$

Current is carried by $\mathrm{Cu}^{2+}$ and $\mathrm{SO}_{4}^{2-}$ in the solution $\mathrm{Cu}^{2+}$ ions go to cathode and get reduced to metal copper and deposited on it. The $\mathrm{SO}_{4}^{2-}$ ions move towards anode but are difficult to get oxidized. So at anode oxidation of $\mathrm{OH}^{-}$ions (produced by the self-ionization of water) takes place in preference to $\mathrm{SO}_{4}^{2-}$.

So, the reaction at anode is

Table 1. Bath conditions for preparation of copper powder.

\begin{tabular}{cc}
\hline Condition & Quantity \\
Copper & $13 \mathrm{~g} / \mathrm{L}$ \\
Temperature & $30^{\circ} \mathrm{C}-35^{\circ} \mathrm{C}$ \\
Anode current density & Low $-400 \mathrm{~A} / \mathrm{m}^{2} ;$ High $-550 \mathrm{~A} / \mathrm{m}^{2}$ \\
Cathode current density & Low $-800 \mathrm{~A} / \mathrm{m}^{2} ;$ High $-1100 \mathrm{~A} / \mathrm{m}^{2}$ \\
Cell potential & $5 \mathrm{~V}$ \\
Additives & $1 \mathrm{wt} \%$ boric acid or glycerine \\
\hline
\end{tabular}




$$
\begin{gathered}
2 \mathrm{H}_{2} \mathrm{O} \rightarrow 2 \mathrm{H}^{+}+2 \mathrm{OH}^{-} \\
2 \mathrm{OH}^{-} \rightarrow \mathrm{H}_{2} \mathrm{O}+\frac{1}{2} \mathrm{O}_{2}(\mathrm{~g})+2 \mathrm{e}^{-}
\end{gathered}
$$

The net reaction at anode:

$$
\mathrm{H}_{2} \mathrm{O} \rightarrow 2 \mathrm{H}^{+}+\frac{1}{2} \mathrm{O}_{2}(\mathrm{~g})+2 \mathrm{e}^{-}
$$

Thus during the electrolysis of $\mathrm{CuSO}_{4}$ solution, the current is carried by copper ions and sulphate ions, but the ions which travel in the electrode reactions are $\mathrm{Cu}^{2+}$ and $\mathrm{OH}^{-}$. Liberation of $\mathrm{H}^{+}$makes the solution around anode more acidic.

The EDS results are shown in Figure 1 indicating presence of some amount of the oxygen phase in the copper powder prepared.

\subsection{Particle Size Analysis}

Particle size analysis results and specific surface area of various samples of copper powder prepared under different bath conditions have been summarised in Table 2. At low cathode current density of $400 \mathrm{~A} / \mathrm{m}^{2}$, particle size was $8.8 \mu \mathrm{m}$ (surface weighted mean), with a specific surface area of $0.7 \mathrm{~m}^{2} / \mathrm{g}$ could be prepared. Particle size distribution in this sample is shown in Figure 2, which is very broad.

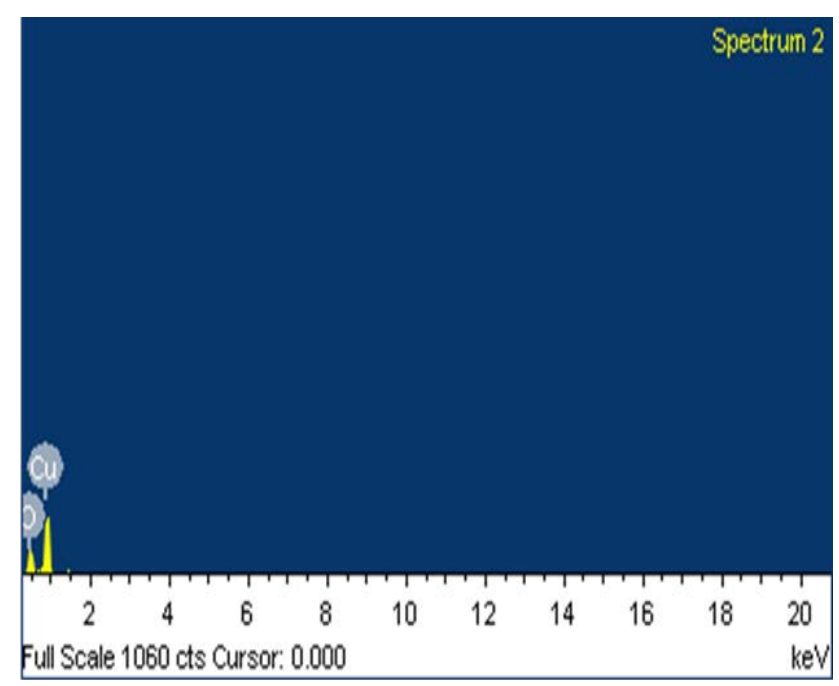

Figure 1. EDS spectrum of the copper powder prepared using high current density.

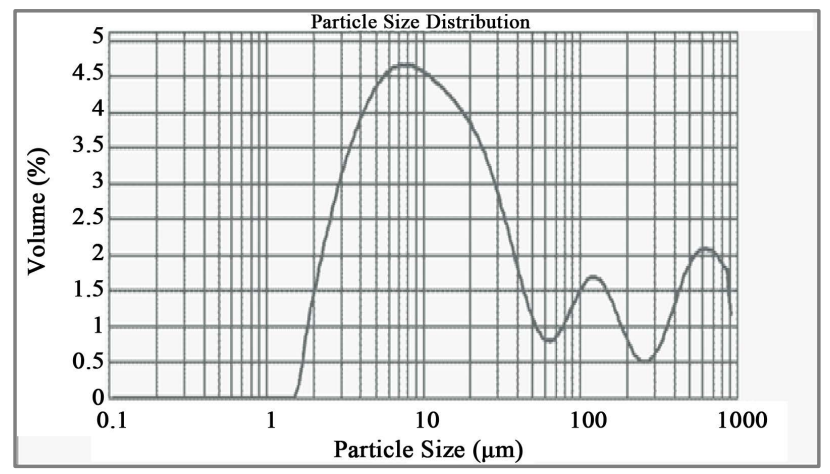

Figure 2. Particle size distribution in copper powder prepared at low current density. 
Addition of $1 \mathrm{wt} \%$ boric acid to the electrolyte gave better mass deposition of copper on electrode due to the increased current efficiency of the electrolytic cell. When boric acid reacts with the copper sulphate solution it produces the $\mathrm{H}^{+}$ions

$$
\mathrm{B}(\mathrm{OH})_{3}+\mathrm{H}_{2} \mathrm{O} \rightarrow \mathrm{B}(\mathrm{OH})_{4}^{-}+\mathrm{H}^{+}
$$

In this reaction boric acid interacts with water molecules to form the tetrahydroxyborate ion and hydrogen ions. Boric acid was found to prevent the rate of electro reduction of copper on stainless steel by an order of magnitude [7]. Therefore, the particle size obtained in this case was significantly smaller $(5.2 \mu \mathrm{m})$ than the particle size obtained at low current density, and consequently a marginal increase in specific surface area. Particle size distribution in this sample is shown in Figure 3, which is narrower as compared to earlier one (Figure 2).

The other additive was glycerine which is a non-electrolyte. When glycerine was added in the electrolyte it created the obstacles in direct deposition of copper particle, due to which the copper particles deposited in this case were finer in size. As shown in above results, the particle size obtained by glycerine addition was $8.3 \mu \mathrm{m}$ but with no change in specific surface area indicating non suitability of such additives to the bath for lowering the particle size in the deposits. Particle size distribution in this sample is shown in Figure 4.

Table 2. Size and specific surface area of the copper powder particles obtained from different bath conditions.

\begin{tabular}{|c|c|c|c|c|c|c|c|c|}
\hline S. No & Bath condition & $\begin{array}{l}\mathrm{d}(0.1) \\
(\mu \mathrm{m})\end{array}$ & $\begin{array}{l}\mathrm{d}(0.5) \\
(\mu \mathrm{m})\end{array}$ & $\begin{array}{c}\mathrm{d}(0.9) \\
(\mu \mathrm{m})\end{array}$ & $\begin{array}{c}\text { Specific } \\
\text { surface area } \\
\left(\mathrm{m}^{2} / \mathrm{g}\right)\end{array}$ & $\begin{array}{c}\text { Surface weighted } \\
\text { mean } \\
(\mu \mathrm{m})\end{array}$ & $\begin{array}{c}\text { Volume } \\
\text { weighted mean } \\
(\mu \mathrm{m})\end{array}$ & $\begin{array}{l}\text { Volume } \% \text { of particle } \\
\text { size less than } 1 \mu \mathrm{m}\end{array}$ \\
\hline 1 & Low current density & 3.4 & 13.2 & 418.2 & 0.7 & 8.8 & 97.8 & - \\
\hline 2 & Boric acid & 2.6 & 6.6 & 15.5 & 1.1 & 5.2 & 8.0 & - \\
\hline 3 & Glycerine & 3.2 & 13.2 & 101.6 & 0.7 & 8.3 & 47.8 & - \\
\hline 4 & High current density & $140 \mathrm{~nm}$ & $230 \mathrm{~nm}$ & 1.6 & 23.2 & $258 \mathrm{~nm}$ & $611 \mathrm{~nm}$ & 73.1 \\
\hline
\end{tabular}

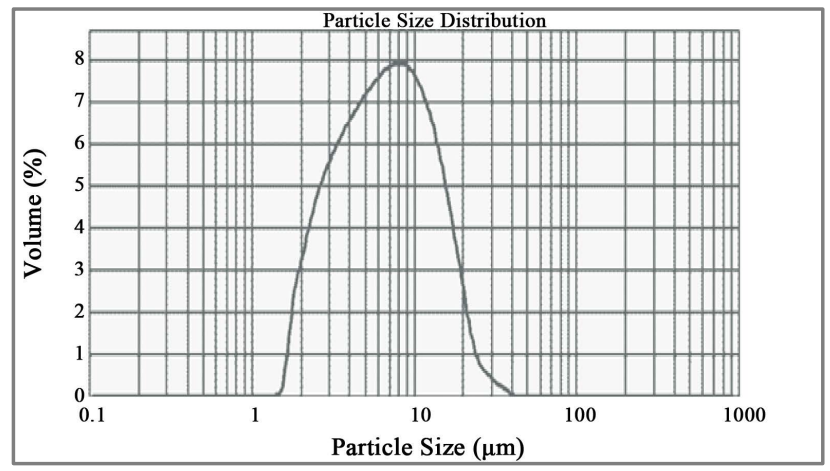

Figure 3. Particle size distribution in copper powder prepared after addition of boric acid to the bath.

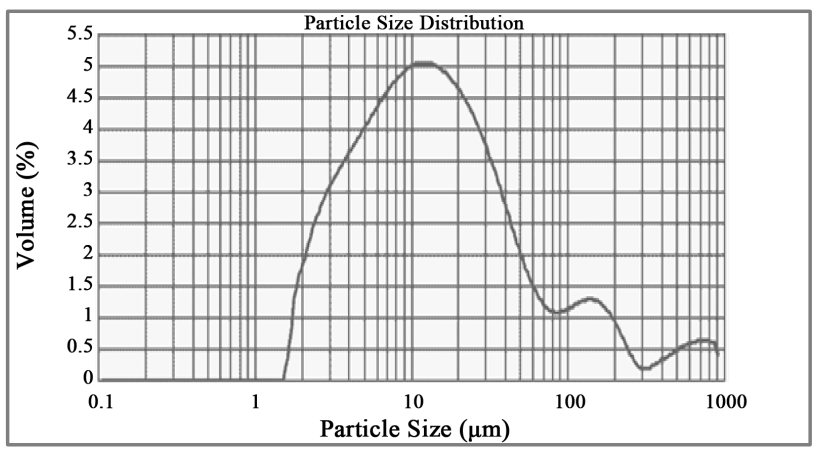

Figure 4. Particle size distribution in copper powder prepared after addition of glycerine to the bath. 
From the results shown in Table 2, it can be seen that near nano copper powder can be prepared by applying high current density to the bath. The metal powder deposits can be obtained at current densities higher than limiting diffusion value. The increasing over potential leads to increased nucleation rate, as well as the number of sites suitable for instantaneous dendrite growth initiation. The number of nucleation sites on the initial surface is obviously limited, while the nucleation on the growing grains can take place continuously. Assuming that powder particles and powder sub particles are the product of further dendrite growth on nuclei formed on the initial surface and the particles themselves, respectively, it is easy to explain the well-known fact that powder particle size decreases with increasing current density. In this sample particle sizes was found to be $258 \mathrm{~nm}$, with a narrow particle size distribution (Figure 5). The volume percentage of the particle size less than $1 \mu \mathrm{m}$ is 73.1 (Table 2). The specific surface area of this sample was $23.2 \mathrm{~m}^{2} / \mathrm{g}$, which is the maximum among all these cases. This is as per known fact that as the particle size decreases the total surface area increases for the same mass of the powder.

\subsection{Morphology}

Morphology of these copper powder particles have been shown in Figures 6-9.

The powder particles produced using low and high current density appears to be irregular shape (Figure 6 and Figure 7). With increased current density, morphology of copper powder deposits was seen to change from compact to massive dendrites (Figure 10). The massive dendrites broke and converted into small irregular shape particles during the deagglomeration. Addition of boric acid to the bath converted the particle shape into spheroid shape (Figure 8), while the addition of glycerine to the bath gave equant shape particles (Figure 9).

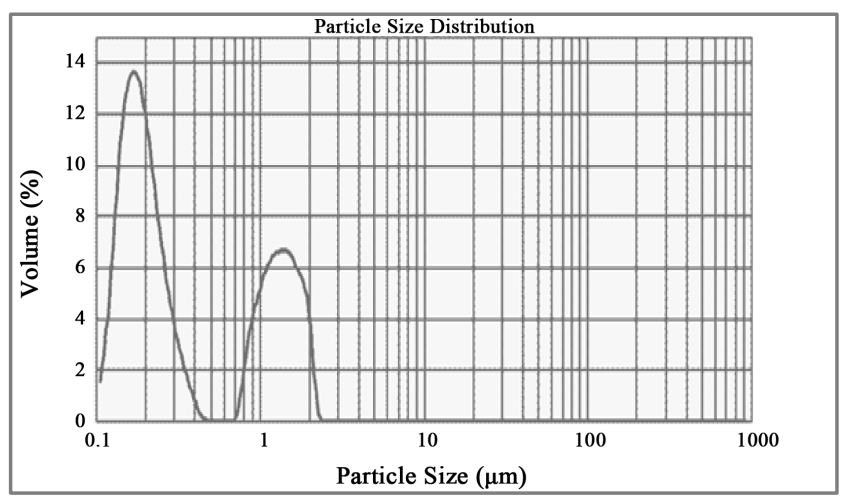

Figure 5. Particle size distribution in copper powder prepared at high current density.

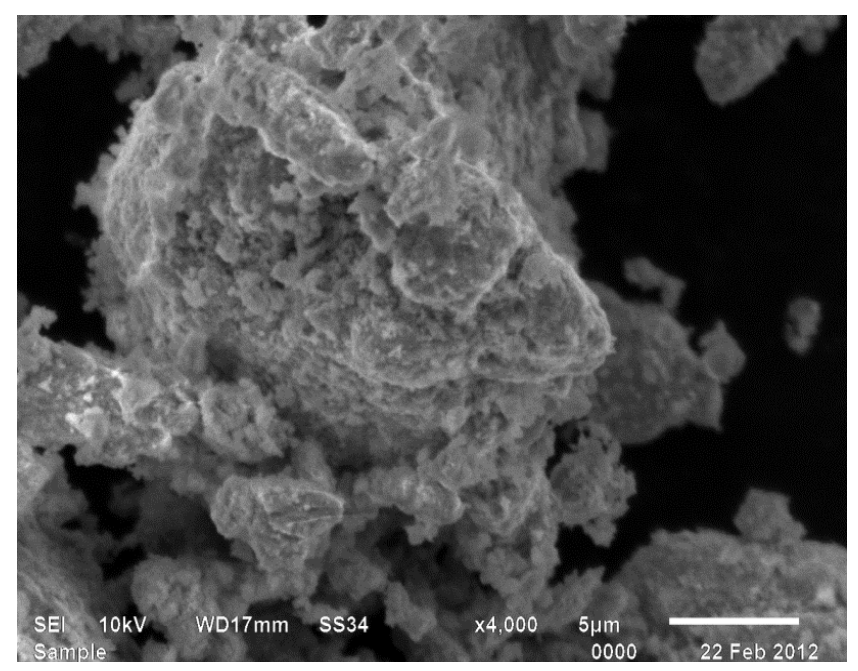

Figure 6. SEM of copper powder prepared at low current density. 


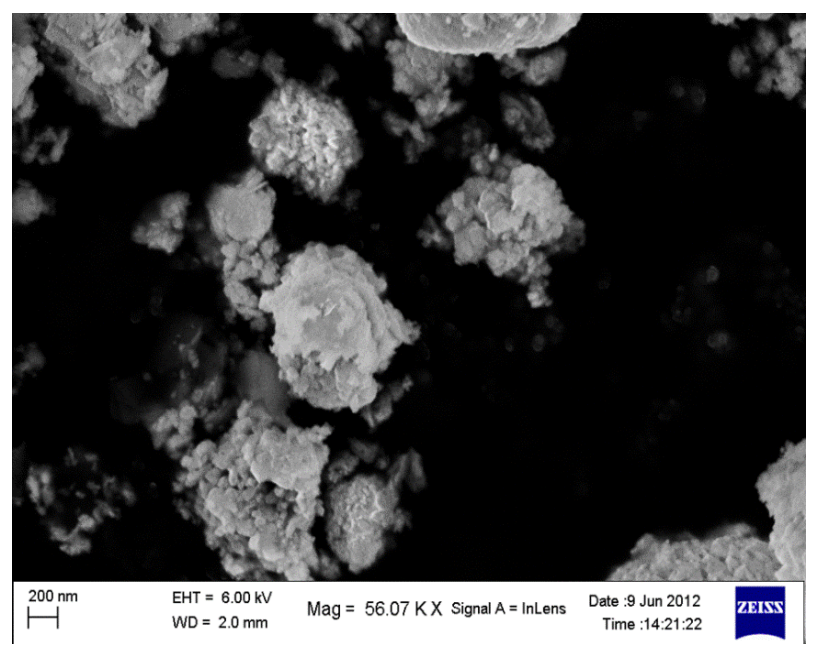

Figure 7. SEM of copper powder prepared at high density.

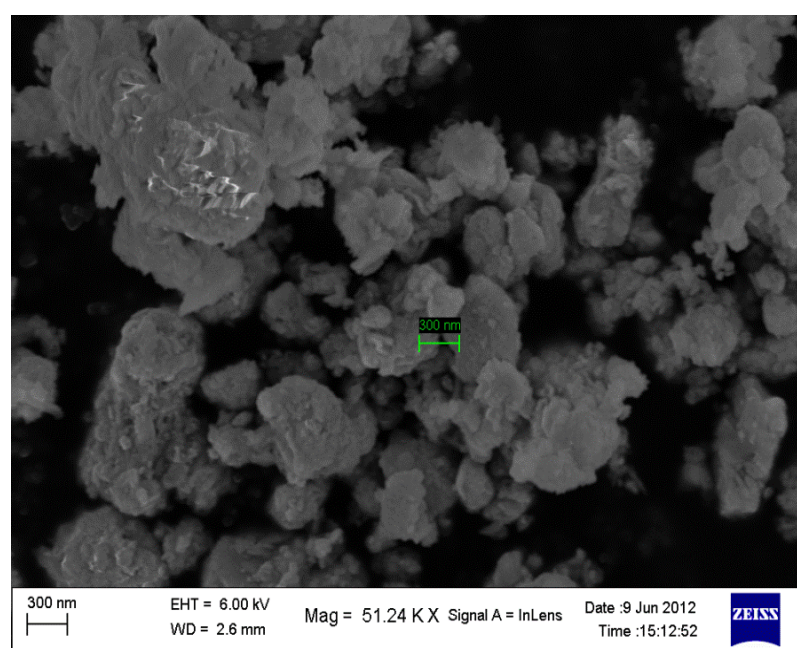

Figure 8. SEM of copper powder prepared by addition of boric acid.

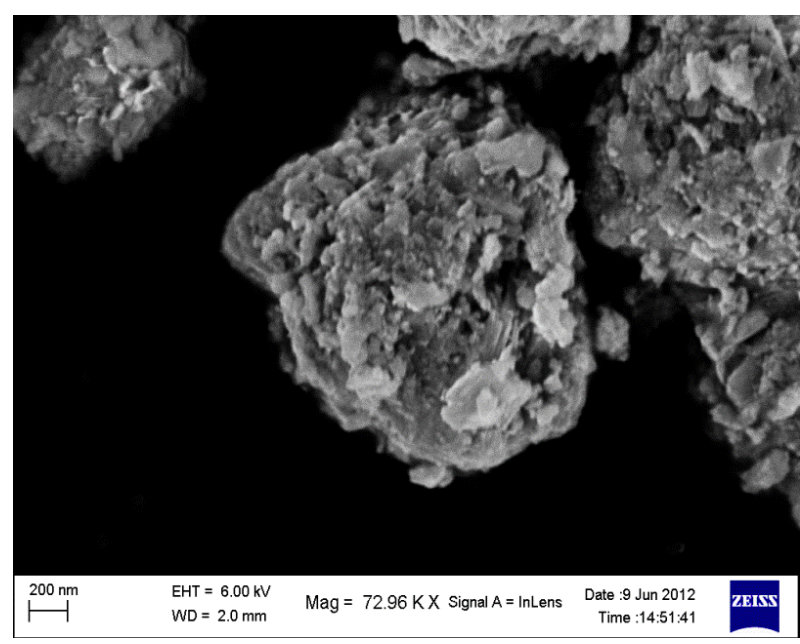

Figure 9. SEM of copper powder prepared by addition of glycerine. 


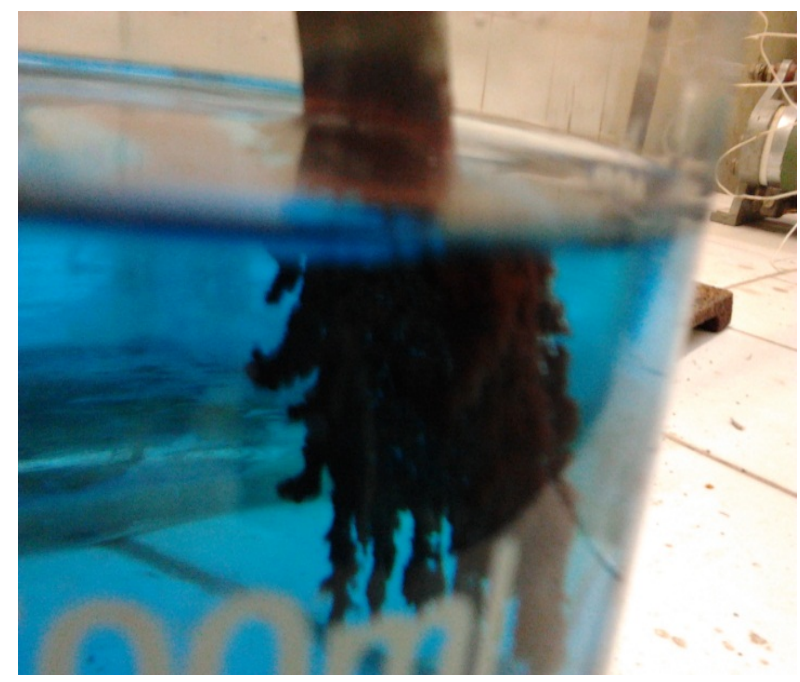

Figure 10. Deposition of copper powder on cathode showing massive dendrites.

\section{Conclusions}

The near nano copper powder was prepared by electrolytic method. These particles were generated when high current density was applied through the bath.

The particle size in copper powder produced was found to be $258 \mathrm{~nm}$, with a narrow particle size distribution. The specific surface area of these particles was $23.2 \mathrm{~m}^{2} / \mathrm{g}$ and the shape was irregular.

\section{References}

[1] Chatopadhyay, K.K. and Banerjee, A.N. (2009) Introduction to Nanoscience and Nanotechnology. PHI Learning, New Delhi, 1-5.

[2] Gordillo, G. and Hailey, X. (2004) Nanopowder Production: A Comparison of Several Methods. NSF-REU Summer, Chicago, 1-19.

[3] Qiu, Z., Zhi-Mao, Y., Bing-jun, D., Xin-zhe1, L. and Yingjuan, G. (2010) Preparation of Copper Nanoparticles by Chemical Reduction Method Using Potassium Borohydride. Transactions of Nonferrous Metals Society of China, 20, 240-244.

[4] Theivasanthi, T. and Alagar, M. (2010) X-Ray Diffraction Studies of Copper Nanopowder. Archive of Physics Research, 1, 112-117.

[5] Nikolic, N.D. and Popov, K.I. (2012) Electrochemical Production of Metal Powders. Springer, Berlin, 125-186.

[6] Berry, D.F. and Klar, E., Production of Copper Powders (1998) ASM Handbook. Powder Metal Technologies and Applications, 7,132-140.

[7] Levi, C., Romalo, J.B. and Shaw, J.K. (1970) Copper Electroplating in Citric Acid Bath. US Patent No. 3684666A. 
Scientific Research Publishing (SCIRP) is one of the largest Open Access journal publishers. It is currently publishing more than 200 open access, online, peer-reviewed journals covering a wide range of academic disciplines. SCIRP serves the worldwide academic communities and contributes to the progress and application of science with its publication.

Other selected journals from SCIRP are listed as below. Submit your manuscript to us via either submit@scirp.org or Online Submission Portal.
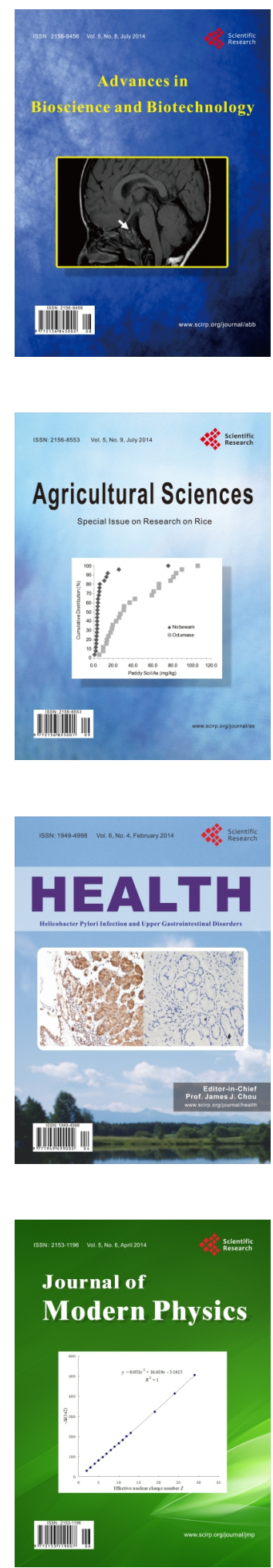
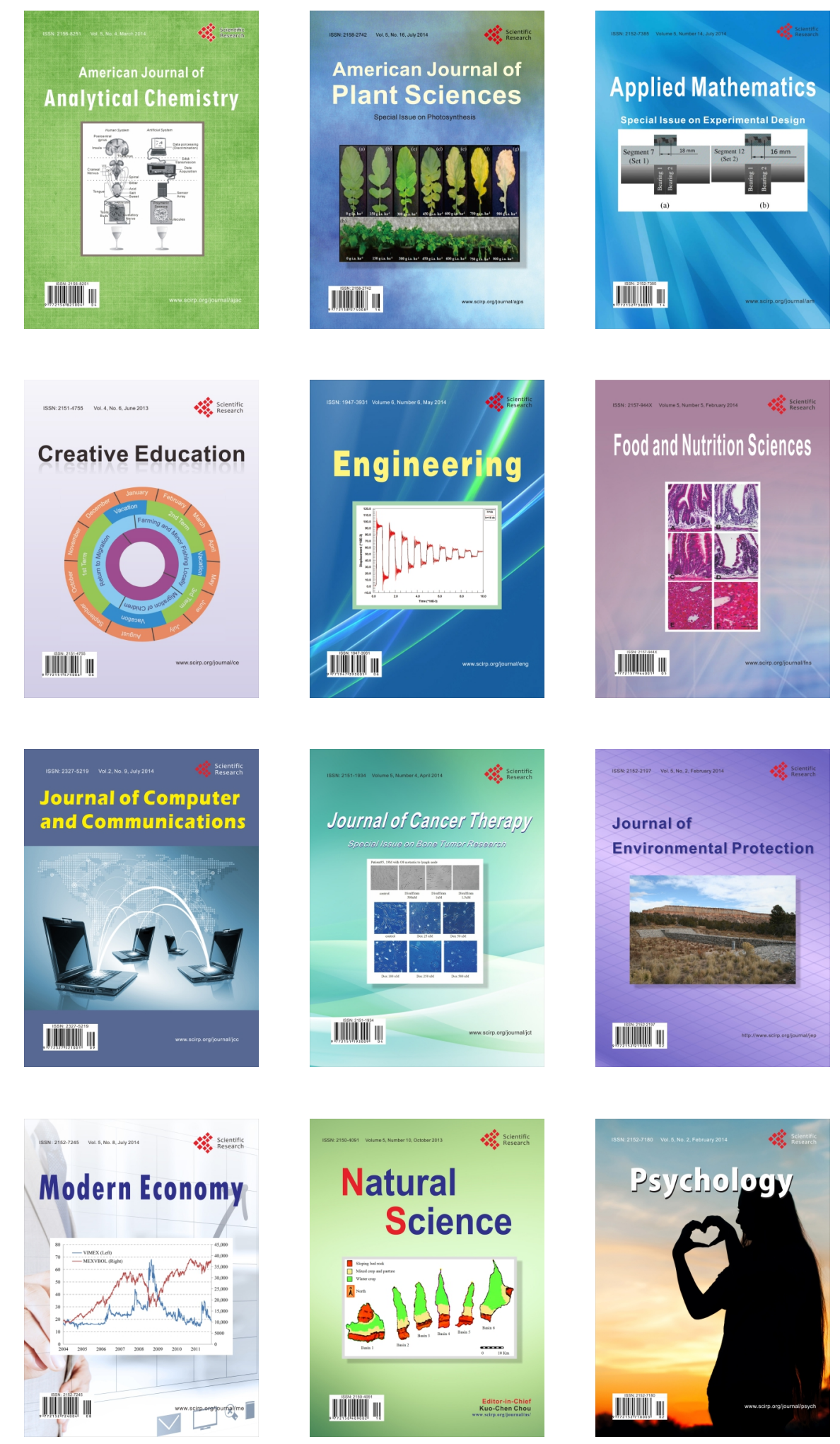